Л. М. Черноватий // Компаративістика і типологія у сучасній лінгвістичній науці: здобутки і проблеми. - Донецьк : ДонНУ, 2004. - С. 229-234. 4. Черноватий Л. М. Типологія термінів як інструмент для визначення змісту навчання майбутніх перекладачів / Л. М. Черноватий // Вісник КНУ імені Тараса Шевченка. - Київ : ВПЦ «Київський ун-т», 2006. - № 40. - С. 4144. 5. Hansen G. Translationskompetenz - Woher Kommt Sie Und Was Ist Das? // Forum Translationswissenschaft. - Band 18. - S. 2-14. 6. Nord Ch. Loyalty and Fidelity in Specialized Translation. CONFLUÊNCIAS - Revista de Tradução Científica e Técnica, N. ${ }^{4}$, Maio 2006. P. 29-41. 7. Pym A. Redefining Translation Competence in an Electronic Age [Електронний pecypc] / Defence of a Minimalist Approach, Meta. - 2006. - № 48 (4). - P. 481-497. - Режим доступу: http://www.erudit.org/revue/meta /2003/v48/n4/008533ar.pdf. 8. Robinson D. Becoming a Translator: An Accelerated Course. - London \& New York : Routledge. - 2007. - 143 p.

УДК 378.016:91:373.55

Ольга Бондаренко, Світлана Мантуленко

\title{
РЕТРОСПЕКТИВНИЙ АНАЛІЗ СТАНОВЛЕННЯ ІДЕЇ ПРОФЕСІЙНОЇ ОРІЕНТАЦІЇ
}

Бондаренко О. В., Мантуленко С. В. Ретроспективний аналіз становлення ідеї професійної орієнтації.

У статті визначається актуальність досліджуваної проблеми шляхом виокремлення суперечностей, наявних між суспільними потребами та їі реальним станом. Авторами здійснено ретроспективний аналіз розвитку ідеї професійної орієнтації підростаючого покоління; визначено історичні передумови іiі становлення, залежність від політичного, соціально-економічного та культурного розвитку країни.

Ключові слова: професійна орієнтація, профорієнтаційна робота, професійна диференціація, професійна підготовка, профільне навчання.

Бондаренко О. В., Мантуленко С. В. Ретроспективный анализ становления идеи профессиональной ориентации.

В статье определяется актуальность исследуемой проблемы путем выявления противоречий, имеющихся между общественными потребностями и её реальным состоянием. Авторами осуществлен ретроспективный анализ развития идеи профессиональной ориентации подрастающего поколения; определены исторические предпосылки её становления, зависимость от политического, социально-экономического и культурного развития страны.

Ключевые слова: профессиональная ориентация, профориентационная работа, профессиональная дифференциация, профессиональная подготовка, профильное обучение.

Bondarenko O. V., Mantulenko S. V. Retrospective analysis of the idea generation for professional orientation.

The urgency of the problem is determined by identifying the contradictions existing between the needs of society and its real condition. The authors carried out a retrospective analysis of the idea of professional orientation of the younger generation. The historical background of the idea formation is defined as well as its dependence on the political, socio-economic and cultural development of the country. 
Key words: professional orientation, vocational guidance work, professional differentiation, vocational training, subject oriented instruction.

У Концепції державної системи професійної орієнтації населення зазначається, що «в умовах глобалізації та посилення конкуренції у світовому економічному просторі загострюється проблема формування, відтворення та використання трудового потенціалу» [7], який визначається характером реалізації особистістю здатності до праці і значною мірою залежить від професійного вибору та успішності здобуття професії.

Аналіз нормативних положень документів, які регламентують профорієнтаційну роботу серед молоді (Закону України «Про загальну середню освіту», Концепції профільного навчання в старшій школі, Положення про організацію професійної орієнтації населення), наукової літератури з організації профорієнтаційної роботи в загальноосвітніх закладах та ii реального стану дозволив виокремити низку суперечностей, наявних між: потребами суспільства у фахівцях 3 високим рівнем професіоналізму, здатних до постійного саморозвитку й самовдосконалення та несформованістю професійної спрямованості у більшості випускників загальноосвітніх шкіл; соціально-педагогічними вимогами свідомого і самостійного вибору професії і недостатньою інформованістю підростаючого покоління про складний світ професій та потреби ринку праці тощо.

Вітчизняні науковці (М. Коломієць, С. Таточенко) одностайні в тому, що усунення згаданих вище суперечностей можливе за цілеспрямованої організації роботи з професійної орієнтації молоді, яка має сприяти посиленню конкурентоспроможності працівника на ринку праці і досягненню продуктивної зайнятості населення.

Проблема професійної орієнтації не $є$ новою. Першими, хто вивчав питання професійної орієнтації підростаючого покоління, вважають А. Біне, Ф. Гальтона, Г. Мюнстерберга, Ф. Парсона, Л. Термена, якими було розроблено тести для визначення професійних здібностей особистості.

Згодом психолого-педагогічні основи професійного самовизначення старшокласників розкрито Л. Виготським, І. Коном, О. Лентьєвим, В. Моляко та ін., чинники та мотиви вибору майбутньої професії старшокласниками досліджували $Є$. Клімов, Р. Немов, Г. Щукіна, П. Якобсон, С. Таточенко, В. Харламенко та ін. Професійна орієнтація школярів на певні види професійної діяльності була предметом дослідження С. Загребельного, I. Жерноклєєва, Т. Осипової та ін.

Ще В. Сухомлинський зазначав, що «успіх у будь-якій практичній справі вимагає не лише знання цієї справи відповідно до сучасних вимог, але й своєрідного історичного аспекту мислення, необхідного бачення педагогічних явищ в їх багаторічному розвиткові, розуміння, що, як, і звідки бере свій початок» $[11$ c. 58]. Тому метою пропонованої статті $\epsilon$ ретроспективний аналіз розвитку та становлення ідеї професійної орієнтації особистості.

Аналіз наукової літератури дозволяє стверджувати, що розвиток і становлення профорієнтаційної роботи знаходиться в прямій залежності від політичного, соціальноекономічного та культурного розвитку нашої країни, оскільки всі реформи, які відбувалися в загальноосвітній школі, були тісно взаємопов'язані з тими перетвореннями, що відбувалися в державі.

Перші спроби підготовки підростаючого покоління не лише до життя, а й до майбутньої професії можна простежити в педагогіці східних слов'ян ще на початку I тисячоліття. Вже тоді існували відмінності у вихованні дітей залежно від статі дитини: хлопчиків готували до чоловічих видів діяльності (полювання, виготовлення знарядь праці); 
дівчаток до жіночих (збирання, ведення домашнього господарства, догляд за дітьми) [9, с. 55].

В освітній практиці Київської Русі на початку XI століття виникли нижчі школи грамоти (у церковних парафіях, монастирях, просвіта за сприяння мандрівних учителів) та елітні школи учіння книжного (заснована князем Володимиром у Києві). Призначення нижчих шкіл грамоти обмежувалось елементарними уміннями й навичками читання, письма, лічби та релігійного виховання. Окрім того, у цих школах діти оволодівали практичним навичкам ведення діловодства, складання листів, договорів, цифрових рахунків. Навчальновиховний процес вищих шкіл учіння книжного був професійно спрямованим. У цих закладах готували професійних переписувачів-каліграфістів, майстрів будівельної справи для зведення храмів, фахівців з малярства, державних службовців, представників духовенства [8, c. 99]. Взаємодія шкіл грамоти і шкіл учіння книжного за часів Київської Русі була першою спробою надати професійно зорієнтованого характеру загальноосвітній школі.

Вивчення історико-педагогічних джерел засвідчує той факт, що саме період XVXVIII ст. ознаменувався розвитком ідеї профілізації загальної освіти завдяки утворенню козацьких та січових шкіл. За описом історика й педагога С. Сірополка [10], січова школа при церкві святої Покрови складалася з двох відділень: у першому навчалися козаки як майбутні паламарі, дяки та диякони; у другому - сироти та хрещеники козацької старшини, яких навчали грамоті, співу, військовому ремеслу. У такий спосіб у січових школах робилися успішні спроби професійної орієнтації з виокремленням у навчально-виховному процесі релігійного й військово-спортивного профілів.

У період реформування шкільної освіти Петром I, було закладено основи державної загальноосвітньої спеціальної школи, що сприяло розвитку шкіл нового типу. У першій половині XVIII ст. було відкрито кілька спеціальних шкіл: інженерних, артилерійських, медичних, іноземних мов. Починаючи з 1721 року функціонують гірничорудні училища, у яких разом із вивченням загальноосвітніх навчальних предметів учні здобували також спеціальну підготовку. Пізніше відкриваються ремісничі, сільськогосподарські школи та навчальні заклади окремих видів професійної школи: морехідні, художньо-промислової освіти [8].

Визначальним в українській національній освіті було створення колегіумів, кількість і значення яких в Україні XVIII ст. поступово зростала. Закладом з широким обсягом освіти, де чітко прослідковується професійна орієнтація, був Харківський колегіум (1738 р.). У ньому викладали граматику, піїтику, риторику, філософію, богослов'я, а в 1765 р. було створено класи французької і німецької мов, математики, інженерної справи, артилерії, геодезії, вокалу й інструментальної музики [5, с. 57].

Теоретичне обгрунтування необхідності здійснення професійної орієнтації того часу знаходимо у працях видатних українських науковців, просвітителів А. ПрокоповичаАнтонського, Г. Сковороди, Ф. Янковича. Усі вони наголошували на необхідності пізнання природи дитини, іiі нахилів, інтересів та врахуванні їх у вихованні й навчанні задля подальшої орієнтації на майбутню професію.

Так, наприклад, Г. Сковорода першим в історії вітчизняної педагогічної думки висуває ідею природного виховання. Він уважав, що формування людини має бути спорідненим з їі природою, під якою філософ-просвітитель розумів обдарування, схильності, дані від народження. У своїх творах Г. Сковорода наголошує на необхідності раннього пізнання природи дитини і визначення виховання відповідно до природних обдарувань. Новим словом в українській педагогіці було застереження батьків і вихователів про наслідки обраного без урахування природних можливостей навчання та життєвого шляху [9, с. 56].

Відомий науковець А. Прокопович-Антонський (1763-1848) у праці «Про виховання»

Педагогіка вищої та середної школи. - 2015. - Вип. 45 
стверджував: «Навчальний процес необхідно узгоджувати з силами та даруваннями молодої людини, розміряти труди про нього й старання. Ніхто не народжується у світі, не одержавши до чого-небудь здібності. Внутрішня схильність завжди готова розкритися в нас, потрібно тільки вдало доторкнутися до неї. Пізнавши здібності розуму, належить уживати засоби, які сприятимуть розвитку їх і спрямуванню до доброї і рятівної мети» [1, с. 351]. На його думку, важливий момент у навчанні - це виявлення здібностей учнів і створення необхідного для їхнього подальшого розвитку середовища, причому, зважаючи на різні здібності учнів до різних предметів, не можна вимагати від різних учнів однакового обсягу наукових знань та умінь. Такі вимоги К. Яновський уважав антипедагогічними і в такий спосіб уже в XIX ст. відстоював ідеї професійної орієнтації і профільної диференціації як найприродніші і такі, що відповідають різнобічному розвитку вихованців [1, с. 354].

Узагальнюючи все вище зазначене, варто наголосити на тому, що зародження та становлення ідеї професійної орієнтації у цей період відбувалося поступово - від відмінностей у вихованні дітей залежно від статі, рекомендацій щодо врахування індивідуальних особливостей до виникнення шкіл 3 професійним спрямуванням. Найбільш важливих зрушень у розв’язанні цього питання школа зазнала у XVIII ст., про що свідчить поширення мережі загальноосвітніх і професійних навчальних закладів 3 практичною професійною спрямованістю.

Подальшого розвитку ідея професійної орієнтації мала місце в середині XIX століття, починаючи з розподілу гімназій на класичні та реальні. Метою класичних гімназій була підготовка до вступу в університети, а реальні гімназії готували до практичної діяльності і до вступу до спеціалізованих навчальних закладів. Основна різниця між класичними та реальними гімназіями полягала в різному обсязі годин, які відводились на викладання природознавства, яке в реальних гімназіях було поглибленим. Окрім того, закінчення реальної гімназії не давало права всім випускникам на вступ до університету.

Після революції 1917 року серед принципів, на підставі яких розбудовувалася нова школа в нашій країні, були різнотипність і диференціація навчальних закладів. У 1918 році Наркомос України прийняв положення про трудову школу УСРР, згідно з яким у старших класах середньої школи виокремлювались три напрями поглибленого вивчення предметів: гуманітарний, природничо-математичний і технічний, але цю схему не було реалізовано [7, c. 14].

На початку XX століття ідея професійної орієнтації набуває вигляду профільного навчання в межах одного навчального закладу. У цей час схвалюються ідеї спеціалізації у старших класах, яка відповідала б індивідуальним інтересам учнів та задовольняла потреби вищої школи. Профільним дисциплінам відводилось 28-30 відсотків навчального навантаження. Так, уже в 1919 році в Україні діяло 5024 початкових шкіл, 1211 вищих початкових училищ, 865 гімназій, 72 реальних, 89 комерційних, 19 торгових, 53 духовних училища $[8$, с. 78$]$.

Серед праць, присвячених досліджуваній проблемі, необхідно відзначити роботи відомого педагога і психолога П. Каптерева. Він підкреслює, що до старшого шкільного віку, коли розумові нахили учнів ще не визначились, не можна вводити такі предмети, які для свого засвоєння вимагають особливих здібностей, особливих розумових нахилів; спочатку потрібно давати те, що однаково необхідно всім, хто хоче бути освіченою людиною [9, с. 58]. Тим самим вказуючи на необхідність диференціації у старших класах, в основу якої мають бути покладені індивідуальні особливості з урахуванням психологічного аспекту.

Отже, характерними особливостями цього періоду $є$ зародження та розвиток 
професійної та предметної диференціації, яка органічно поєднувалася з загальноосвітньою підготовкою.

У 1920 роках в Україні трудовий принцип стає головним у навчанні і професійній підготовці учнів. Було створено оригінальну систему освіти, яка суттєво відрізнялась від російської і була спрямована на отримання певної професії. Підготовка до майбутньої трудової діяльності здійснювалася професійними школами різних типів, де навчались учні після закінчення семирічної трудової школи. Найбільш поширеними були індустріальнотехнічні, сільськогосподарські, соціально-економічні, медичні, мистецькі, ремісничопромислові, будівельні, транспортні школи [9, с. 59].

Вагомий внесок у теоретичне розроблення основ трудової школи зробив А. Луначарський. Розкриваючи сутність та завдання нової школи, він говорив: «Школа повинна бути трудовою, викладання в ній повинно мати політехнічний характер, але не вузькопрофесійний, як про це говорять і не правильно розуміють» [9, с. 59].

Орієнтуючись на трудову підготовку, було зроблено спробу диференціювати учнів за здібностями. Для учнів першого ступеня, які не здатні на високому рівні опанувати навчальну програму, загальноосвітні дисципліни викладались скорочено, але при цьому збільшувалась кількість практичних занять у шкільних майстернях. Окрім того, у зв'язку 3 диференціацією учнів за здібностями й інтересами було започатковано поглиблене вивчення окремих предметів: природничо-математичних, словесно-історичних тощо.

У навчальному процесі реалізувалась обов'язкова для всіх учнів програма-мінімум і не обов'язкова за вибором програма-максимум. Учні могли працювати в тому темпі, який відповідав їхнім індивідуальним можливостям. Однак професіоналізація школи в цей період не мала того ефекту, якого очікували, через слабкість матеріальної бази, відсутність спеціальних програм професійної підготовки.

Окресленний історичний етап характеризується як період інтеграції загальної освіти та професійних знань, установлення взаємозв'язку з промисловими та сільськогосподарськими підприємствами. Особливістю цього періоду, як стверджує більшість спеціалістів 3 історії педагогіки, $є$ спроба розв'язання через трудове виховання завдань, формування світогляду учнів, що призвело до перевантаження практичною діяльністю та зниження рівня загальноосвітньої підготовки.

У 50-х роках ідея професійної орієнтації тісно пов'язана з активізацією диференціації навчання. Цьому передували причини передовсім соціального характеру. Уперше у практиці школи було визначено ідею зовнішньої профільної диференціації, яку було подано у формі «шкіл з поглибленим вивченням дисциплін» (фізико-математичні, художні, музичні, 3 поглибленим вивченням іноземних мов тощо.). Це надало змогу готувати дітей з яскраво вираженими здібностями і високим рівнем знань 3 профільних дисциплін.

Згодом з метою посилення професіоналізації школи був прийнятий Закон «Про зміцнення зв'язку школи 3 життям і про подальший розвиток системи народної освіти» (1958 р.). Ініціатори експерименту виходили із того, що диференційоване навчання може стати гнучкою формою системи освіти, яка б відповідала суспільним інтересам та забезпечувала підготовку молоді до практичної діяльності.

Зміст освіти в цей період мав професійно зорієнтований характер і забезпечував зв'язок $з$ життям, умовами, у яких перебувала країна.

Аналіз літератури періоду 60-х, 70-х років засвідчує, що в цей час широкого поширення набули факультативи, які мали на меті розвивати творчі здібності старшокласників, їхні інтереси, зокрема професійні. Для створення програм факультативних курсів залучались

Педагогіка вищої та середної школи. - 2015. - Вип. 45 
учителі, які могли вільно вибирати їх тематику та визначити зміст. Навчальним планом передбачались спеціальні години на факультатив, однак вони виявились не такими ефективними, як очікувалось. Оскільки практика показала, що спроба об'єднати у школі загальноосвітню підготовку з професійною себе не виправдала, було ухвалене рішення, що ознайомлення з основами виробництва буде здійснюватись у процесі вивчення основ наук як природничо-математичних, так i соціально-економічних, через обов'язкові практичні лабораторні заняття з математики, фізики, хімії і біології та за рахунок обов'язкових екскурсій на виробництво, а також через систему трудових занять. Усе це розглядалося як необхідна умова для допрофесійної трудової підготовки учнів на широкій політехнічній основі і як можливість отримання кваліфікованого розряду паралельно із загальною середньою освітою.

На сторінках педагогічної літератури широко обговорювалися питання свідомого вибору професії учнями, завдання трудової політехнічної освіти та шляхи іiі реалізації в загальноосвітній школі (Ю. Аверічев, А. Арсеньєв, Т. Василькова, М. Жидельов, Д. Епштейн, К. Іванович, К. Платонов, В. Чебишева та інші). У цей період особлива увага приділялася діяльності навчально-виробничих комбінатів, які стали центрами трудового і професійного навчання.

Великий інтерес з цього питання викликала розроблена наприкінці 70-х - на початку 80-х років цілісна концепція диференційованого навчання (Ю. Бабанський, Н. Шахмаєв), в основу якої покладено ідею про те, що у школах для учнів певного віку необхідно створювати умови для диференційованого навчання відповідно до їхніх природних задатків і здібностей, у тісному взаємозв'язку з потребами суспільства [9].

Згідно 3 цією концепцією пропонується ввести 3 восьмого класу профільну диференціацію шляхом поглибленого вивчення природничо-математичних i гуманітарних предметів за вибором учнів. Це сприятиме підвищенню якості підготовки учнів з обраного профілю, удосконалить профорієнтацію, підвищить авторитет школи, суттєво скоротить практику репетиторства. Диференційована підготовка буде впроваджуватись поступово шляхом створення для цього необхідних кадрів і матеріально-технічних умов. Перш за все будуть розширені факультативні заняття, розроблені вчителями й затверджені педагогічною радою. До навчального плану буде введено курси за вибором, які будуть обов'язковими для учнів, які їх обрали.

Вибір варіантів диференціації буде прерогативою місцевих органів народної освіти, щоб повною мірою врахувати конкретні умови й можливості [9, с. 62].

Ця ідея набула широкого поширення і практичного втілення наприкінці 1980-х початку 1990-х років у вигляді нових типів освітніх закладів (гімназій, ліцеїв, коледжів), які зосереджують зусилля учнів на поглибленому вивченні окремих предметів, які потрібні їм для подальшого навчання у вищих навчальних закладах. Ідею диференційованого навчання було покладено в основу сучасної концепції профільного навчання старшокласників.

Наприкінці 90-х років ХХ століття створюються основні документи, що визначають нормативно-правову базу профільного навчання: Закон України «Про загальну середню освіту», Національна доктрина розвитку освіти України у XXI столітті, Концепція профільного навчання в старшій школі.

Отже, ідея професійної орієнтації як одне з прогресивних явищ вітчизняної педагогіки у своєму розвитку пройшла складний шлях становлення від поступового посилення уваги до неї, до визначення іiі змісту в контексті диференціації і профілізації навчання, що було зумовлено культурно-історичними та соціально-економічними суспільними змінами. 
Безумовно, ті фундаментальні положення, які в минулому визначали розвиток профтехосвіти в XXI ст., зазнають суттєвих змін. Протягом усього періоду функціонування профтехосвіти часто абсолютизувалась іiі єдина мета - забезпечення галузей народного господарства кваліфікованими робітничими кадрами. На сучасному етапі мета цієї системи суттєво розширюється й передбачає створення умов для професійної самореалізації особистості, задоволення іiі потреб у професійних, освітніх послугах упродовж усього життя [9, с. 63].

Перспективу подальших досліджень убачаємо у визначенні педагогічних умов реалізації ідеї професійної орієнтації в умовах вітчизняної профільної школи.

\section{Література}

1. Антипова Е. И. Ориентация учащихся на педагогическую профессию / Е. И. Антипова // Советская педагогика. $-\quad$ 1986. $-\quad$ № 9. $-\quad$ С. 38-42. 2. Антология педагогической мысли Росии первой половины XIX в. - Москва : Педагогика, 1990. - 608 с. 3. Бібік Н. Науково-методичний супровід у профільній школі / Надія Бібік, Михайло Бурда // Освіта України. - 2004. - 17 серп. (№ 62/63). - С. 4-6. 5. Історія української школи i педагогіки : [хрестоматія] / [В. Г. Кремень (ред.), О. О. Любар (упоряд.)]. - Київ : Знання, 2003. - 766 с. 6. Концепція державної системи професійної орієнтації населення освіти [Електронний ресурс]. - Режим доступу: http://zakon4.rada.gov.ua/laws/show/842-2008\% D0\%BF 7. Концепція профільного навчання в старшій школі // Інформаційний збірник Міністерства освіти і науки України. - 2003. - № 24.- С. 3-15. 8. Любар О. О. Історія української педагогіки: [навч. посіб.] / О. О. Любар, М. Г. Стельмахович, Д. Т. Федоренко ; ред. О. О. Любара. - Київ : Знання; КОО, 2003. - 450 с. 9. Мантуленко С. В. Формування готовності майбутніх учителів географії до профільного навчання старшокласників : дис. ... кан. пед. наук. : 13.00.04 / Мантуленко Світлана Вікторівна. - Кривий Ріг, 2014. - 255 с. 10. Сірополко С. Історія освіти в Україні / підготував Ю. Вільчинський. - [2-е вид.]. Львів : Афіша, 2001. - 664 с. 11. Сухомлинський В. О. Вибрані твори : в 5-ти т. / Василь Олександрович Сухомлинський. - Т. 5 : Статті. - Київ : Рад. шк., 1977. - 639 с.

УДК 372.48:373.1(477)

Володимир Бугрій

\section{ЗАВДАННЯ, ЗМІСТ ТА СТРУКТУРА ІСТОРИЧНОЇ ОСВІТИ В НАВЧАЛЬНИХ ПЛАНАХ І ПРОГРАМАХ ТРУДОВОЇ ШКОЛИ В УКРАЇНІ (20-ті рр. ХХ ст.)}

Бугрій В. С. Завдання, зміст та структура історичної освіти в навчальних планах $\mathrm{i}$ програмах трудової школи в Україні (20-ті рр. ХХ ст.).

Статтю присвячено аналізу завдань, змісту та структури історичної освіти у трудовій школі в Україні у 20-ті pp. XX ст. Встановлено, що в навчальних планах і програмах історична освіта підпорядковувалася головному завданню, яке ставилося перед трудовою школою - підготовці майбутніх працівників промисловості чи сільського господарства, їх вихованню в дусі відданості соціалістичним ідеалам. Історичні знання обмежувалися вивченням трудової діяльності людей і радянської дійсності як абсолютної цінності у порівнянні з минулим. У зв'язку з цим у програмах 1920-х рр. історія як самостійний шкільний предмет скасовувалася, а історичні знання були інтегровані спочатку в курс історії культури, а пізніше в курс суспільствознавства.

Ключові слова: історична освіта, трудова школа, навчальна програма, комплексна програма, суспільствознавство. 